\title{
Benefits of plant strips for sustainable mountain agriculture
}

\author{
Victor Hugo Durán ZuAzo ${ }^{*}$, Carmen Rocío Rodríguez PlegueZuelo ${ }^{1}$, José Ramón Francia MarTíneZ ${ }^{1}$, \\ Armando MARTínez RAYA ${ }^{1}$, Lorenzo ARroyo PANADERO ${ }^{1}$, Belén CÁRCELES RodríGuez ${ }^{1}$, Maria Concepción \\ NAVARRO MOLL ${ }^{2}$ \\ ${ }^{1}$ IFAPA Centro Camino de Purchil, Apdo. 2027, 18080-Granada, Spain \\ ${ }^{2}$ Departamento de Farmacología, Facultad de Farmacia, Universidad de Granada, Campus de Cartuja, 18071, Granada, Spain
}

(Accepted 10 April 2008)

\begin{abstract}
Erosion degrades soil quality in agricultural ecosystems, thereby reducing the productivity of the land. Semi-natural vegetation and diverse cropping systems have been converted into monocultures with low tree densities, leaving the soil unprotected. We evaluated the association in soil- and water-conservation systems with production in traditional almond orchards and the beneficial impact of plant strips in mountainous agriculture. Soil loss, runoff and nutrient loss over a four-year period (2002-2005) were monitored in hillside erosion plots with almond trees under different soil-management systems: (1) non-tillage with sage (Salvia lavandulifolia L. subspecies Oxyodon) strips 3 m wide; (2) non-tillage with rosemary (Rosmarinus officinalis L.) strips, (3) non-tillage with thyme (Thymus baeticus L. Boiss. exlacaita) strips, and (4) conventional tillage on the south flank of the Sierra Nevada (Lanjaron) in south-eastern Spain. Also, the nut yield from almond trees, and the biomass from aromatic-shrub strips were measured. The erosion plots, located on a 35\% slope, were $144 \mathrm{~m}^{2}$ in area. The plant-cover strips, $3 \mathrm{~m}$ wide, ran across the slope. Our results show that the most effective treatment proved to be non-tillage with thyme strips, reducing the annual soil loss by $93 \%$ and runoff by $80 \%$, with respect to conventional tillage. Non-tillage with rosemary strips reduced soil loss by $91 \%$ and runoff by $82 \%$, with respect to conventional tillage, while these percentages were $69 \%$ and $51 \%$, respectively, for non-tillage with sage strips. In addition, all the treatments as a whole, in comparison with conventional tillage, revealed that the plant strips were the decisive factor in the reduction of NPK losses by surface runoff. The average nut yield from non-tillage with sage strips, non-tillage with rosemary strips, non-tillage with thyme strips and conventional tillage during the study period was $2.4,3.2,3.8$ and $4.5 \mathrm{~kg}^{-1}$ tree $^{-1}$, respectively, and the essential oil yield from sage, rosemary and thyme strips was 5.0, 8.7 and $10.8 \mathrm{~L} \mathrm{ha}^{-1}$, respectively. The non-tillage with thyme strips decreased nutrient loading in surface waters and thus had a positive impact on the environment while simultaneously maintaining reasonable almond-production levels. Thus, the combination of orchard trees with shrubs provided a viable option to conserve soil and water in hilly areas with opportunities to increase overall land productivity as well as sustainable agro-environmental measures.
\end{abstract}

almond orchards / aromatic-shrub-cover strips / biomass production / hillslope erosion / mountainous agriculture / soil-management systems

\section{INTRODUCTION}

Soil erosion is widespread and adversely affects significant human-managed ecosystems. It is recognised as a major environmental issue, especially in agricultural areas (Arshad and Martin, 2002) and in the Mediterranean basin, after more than 4.000 years of deterioration (Brandt and Thornes, 1996), the problem is becoming steadily more urgent. The effects are pervasive, and damage is long lasting (Pimentel et al., 1995). Also, it is well known that land areas covered by plant biomass, living or dead, are protected and undergo reduced soil erosion because raindrop and wind energy is dissipated by the biomass layer (Pimentel, 2000, 2006).

\footnotetext{
* Corresponding author: victorh.duran.ext@juntadeandalucia.es
}

Permanent rainfed crops such as almonds (Prunus amygdalus), olives (Olea europaea) and grapes (Vitis vinifera) cover vast areas of the Mediterranean landscape. The acreage of almonds has expanded rapidly into marginal soils of the hillslopes of south-eastern Spain (Faulkner et al., 2003). Trees are widely spaced and the soil in between is kept bare to reduce competition with weeds for the scarce rainfall. Hence, the large areas of bare soil among the trees are vulnerable to erosion. However, it has recently been demonstrated that soil redistribution by human agricultural activity such as tillage can be an even more severe cause of degradation as a result of conversion of shrublands into almond or olive orchards with widely-spaced trees and hardly any plant cover. In particular, the cultivation of almond is feasible primarily in the 
Spanish Mediterranean area in rainfed orchards (92\%) covering immense tracts of land (Franco et al., 2000), with some 661920 ha of almond orchards soon to exceed a production of 204500 t (FAO-STAT, 2007).

Mechanisation has enabled farmers to cultivate marginal soils even on steep hillslopes. This expansion into marginal areas is stimulated by the European Union Common Agricultural Policy, which directly subsidises the modernisation of extensive planting and conversion of shrubland, and also supports rural development and the agro-industry (Beaufoy, 2003). Unfortunately, the expansion of tree crops has not been accompanied by soil conservation measures and, for example, the existing terraces have often even been destroyed (Oñate and Peco, 2005). In this regard, van Oost et al. (2000a) and De Alba (2003) have demonstrated the danger of tillage causing soil loss from fields. On the other hand, van Oost et al. (2000b) pointed out the importance of the landscape structure in the movement of soil from the crest of a sloped field and sedimentation below, which could reach up to $28 \%$ of the losses in annual erosion rates.

In semi-arid regions, torrential rains are the major causes of soil erosion, especially in mountainous areas. In particular, for south-eastern Spain (Sierra Nevada Mountains), strong efforts have been made to curb cropland erosion, primarily by reducing runoff (Martínez et al., 2006; Francia et al., 2006; Durán et al., 2004a, 2008). One solution for runoff control on Mediterranean slopes involves the use of plant covers, which have been shown to improve the physical and chemical properties of the soil (Aranda and Oyonarte, 2005; Durán et al., 2006).

Since ancient times, aromatic and medicinal plants have had wide applications, and continue to be used fresh, frozen or dry, as well as transformed into oils, extracts and essences, primarily for the food, pharmaceutical and cosmetic industries (Weiss, 1997; Miguel et al., 2004; Bogers et al., 2006). Also, beekeepers during spring use these plants for honey (with different aromas and tastes), pollen and bee-glue. A great proportion of aromatic and medicinal plants comes from wild plants, while more marketable species (mint, lemon balm, lavender, chamomile, etc.) are cultivated with conventional or ecological production systems (Lawrence, 1985; Bown, 2001). In this context, the cultivated area of aromatic and medicinal plants in Spain is roughly 7000 ha, of which some 4000 ha are devoted to lavender production. The organic agricultural production is increasing, with about 2300 ha, of which 1700 ha are located in Andalusia. Therefore, the maintenance and cultivation of these types of plants constitute major economic activities for local farmers (Blanco et al., 1996, 1998; Lange, 1998).

Strips of plants, including aromatic species growing on a slope, can diminish erosion by reducing runoff, and consequently avoid nutrient transport (Le Bissonnais et al., 2004; Francia et al., 2006; Owino et al., 2006). Intermittent strips can break up the trajectory of the surface runoff, decreasing the erosive effect and increasing infiltration. As rainfall is a limiting factor for rainfed crops in a semi-arid environment, it is critical to capture a maximum of rainfall while allowing a minimum of runoff.
The agricultural-production process involves fertilisation, often applying more nutrients than required by crops. Such excesses contribute to environmental pollution from both runoff and sedimentation (Wang et al., 2004). Fertiliser, especially nitrogenous, is regarded as the main contributor to nitrate $\left(\mathrm{NO}_{3}-\mathrm{N}\right)$ losses. The quantity of this anion in runoff depends on soil characteristics, the relative rate of plant uptake of nitrogen $(\mathrm{N})$, and several $\mathrm{N}$-transforming processes. Applied phosphorus $(\mathrm{P})$ is rapidly retained as insoluble inorganic compounds which are sorbed to soil particles. Therefore, the losses of soluble phosphate $\left(\mathrm{PO}_{4}-\mathrm{P}\right)$ in surface runoff tend to be quite low. However, P inputs to fresh waters from agricultural lands can accelerate eutrophication via runoff and soil loss from specific sources such as fields varying in tillage and fertility management (Smith et al., 1999). Finally, potassium (K) is a major nutrient used to boost nut yield from almond trees (Basile et al., 2003), and thus a potential contaminant.

The release of absorbed chemicals from soil and their transport in runoff, as in the case of agriculturally applied plant nutrients, may affect the quality of the water bodies receiving these effluents. Numerous studies evaluating agricultural pollution have shown great variability in nutrient losses related to differences in land-use and management practices (Sharpley et al., 1988; Ulen, 1997; Sharpley and Tunney, 2000; Durán et al., 2004b). Therefore, diversification of existing cropping patterns coupled with suitable agro-environmental practices in soil management can provide sustainable agricultural systems that optimise production and maintain high environmental quality. For example, plant strips replacing open tilled areas offer multi-cropping while counteracting erosion.

The aim of this work was to identify the best soilmanagement strategy for almond orchards under the conditions studied. In this work, we study four different soilmanagement systems for this crop in steeply sloping areas of Lanjaron (Granada, SE Spain): non-tillage with sage (Salvia lavandulifolia $\mathrm{L}$. subspecies Oxyodon) strips $3 \mathrm{~m}$ wide; rosemary (Rosmarinus officinalis L.) strips, thyme (Thymus baeticus L. Boiss. exlacaita) strips and conventional tillage. We determined and compared the effects of these systems on soil erosion, surface runoff and nutrient losses, and we measured the nut and biomass yield from almond trees and plant strips, respectively.

\section{MATERIALS AND METHODS}

\subsection{Site description, experimental setting and soil-management systems}

The experiment was conducted under field conditions in the Sierra Nevada mountains (Lanjarón, SE Spain) with a latitude and longitude of $36^{\circ} 54^{\prime} 14.66^{\prime \prime}$ and $03^{\circ} 29^{\prime} 11.89^{\prime \prime}$, respectively, and at an altitude of $580 \mathrm{~m}$ a.s.l.. The area has a Mediterranean climate with a mean annual rainfall of $540 \mathrm{~mm}$ with high variability in intensity and frequency. The soil of the zone, Calcic cambisol (FAO, 1974), has a loamy-soil texture, with $52 \%$ sand, $32 \%$ silt and $16 \%$ clay, $1.03 \%$ organic matter, $0.09 \% \mathrm{~N}, 14.6 \mathrm{mg} \mathrm{kg}^{-1} \mathrm{P}$, and $45 \mathrm{mg} \mathrm{kg}^{-1}$ available $\mathrm{K}$. 


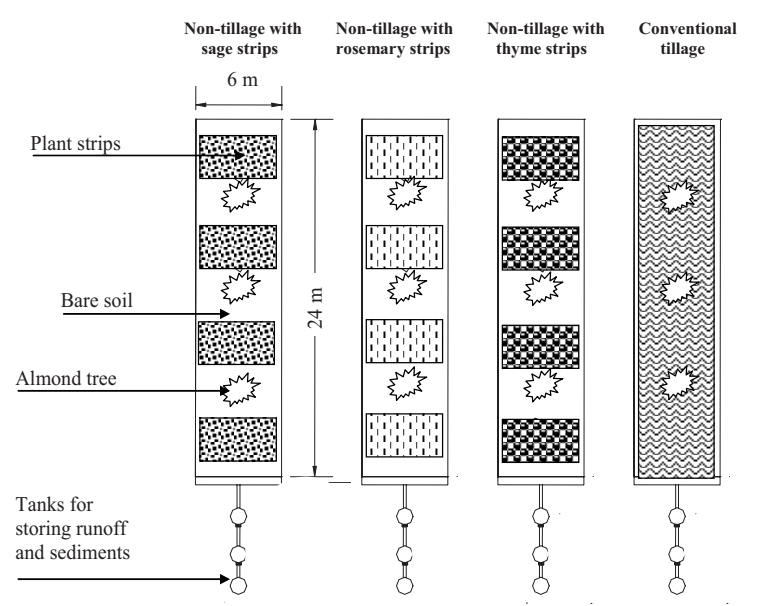

Figure 1. Erosion plots used for different soil-management systems.

The experimental plot was part of a rainfed almond orchard (Prunus amygdalus Basch cv. Desmayo Largueta) with trees spaced $6 \times 6 \mathrm{~m}$. Four erosion plots $(24 \mathrm{~m} \times 6 \mathrm{~m})$ were located on a hillside ( $35 \%$ slope). An erosion plot consisted of a galvanised enclosure, drawer collector, and sediment and runoff collectors (Fig. 1). Each erosion plot contained 3 almond trees with different treatments: one plot with non-tillage and four 3-m-wide strips of sage (Salvia lavandulifolia L. subspecies Oxyodon), a second plot with strips of rosemary (Rosmarinus officinalis L.), a third plot with strips of thyme (Thymus baeticus L. Boiss. exlacaita), and finally, a fourth plot with conventional tillage. Each strip, planted across the slope, was $3 \mathrm{~m} \times 6 \mathrm{~m}$ so that the plot was $50 \%$ covered. The percentage of soil covered by each aromatic plant was recorded before the harvest period by counting the number of grid intersections which intercepted vegetation in $18 \mathrm{~m}^{2}$ (strip with $3 \mathrm{~m} \times 6 \mathrm{~m}$ ), in a 10 by $10 \mathrm{~cm}$ grid (a total of 100 grids). The strips were intended to trap eroded soil and reduce the runoff down the slope. Fertiliser was applied to the treatment plots in the form of 15-15-15 NPK at a nominal rate of $800 \mathrm{~kg} \mathrm{ha}^{-1} \mathrm{yr}^{-1}$ typical of local cultivation practices.

\subsection{Measurements and statistical analysis}

During the four-year monitoring period (2002-2005) the soil loss and runoff from plots were collected and measured after each rainfall event. Three 1-L aliquots were taken from different depths while the content of the tanks was being stirred. The sub-samples were immediately taken to the laboratory, oven-dried at $105{ }^{\circ} \mathrm{C}$, and weighed to determine the suspended sediment concentration. In addition, each runoff sample was analysed for $\mathrm{NO}_{3}, \mathrm{NH}_{4}, \mathrm{PO}_{4}$ and $\mathrm{K}$ concentrations in accordance with standard methods for the examination of waters (APHA, AWWA, WPCF, 1995). At the end of each season the mature almonds were harvested from the trees, and the biomass from aromatic-shrub strips was measured. Also, plant material consisting of leaves and flowers from sage, rosemary

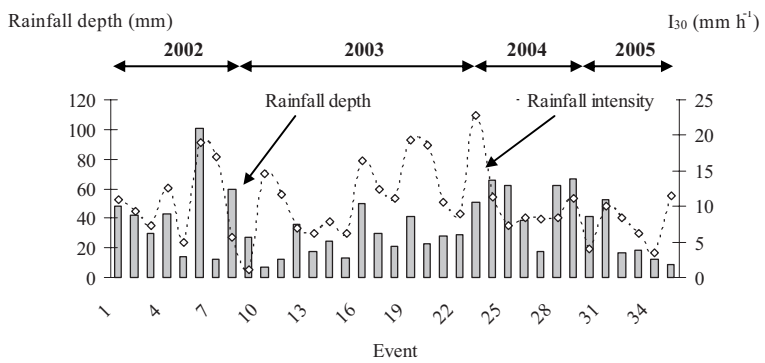

Figure 2. Rainfall and maximum rainfall intensity at $30 \mathrm{~min}\left(I_{30}\right)$ for each event during the study period.

and thyme was taken for determination of essential oil contents (MSC, 1997). The rainfall data were collected from a local meteorological station ( $<100 \mathrm{~m}$ from the plots). For each rainfall event, the average intensity and maximum intensity at $30 \mathrm{~min}\left(I_{30}\right)$ were calculated. From this data, the kinetic energy was calculated by units of energy per unit area and precipitation $\left(E=210+89 \log _{10} I\right)$ (Wischmeier and Smith, 1978). The erosivity index $\left(\mathrm{E} I_{30}\right)$ for each year was calculated according to Wischmeier and Smith (1978) for the monitoring period.

By analysis of one-way analysis of variance (ANOVA), the means of different effects of soil-management systems were compared, and differences between individual means were tested using the Least Significant Difference (LSD) at $P<0.01$. Linear relationships were fitted for runoff, soil loss and rainfall parameters (maximum intensity $I_{30}$ and the erosivity index $\left.\mathrm{E} I_{30}\right)$.

\section{RESULTS AND DISCUSSION}

\subsection{Rainfall and erosivity parameters related to soil loss and runoff}

During the study period (2002-2005), rainfall was typical of the Mediterranean region, being concentrated in autumn and winter. The total rainfall for the first, second, third and fourth year was 378.0, 384.5, 313.1 and $149.2 \mathrm{~mm}$, respectively. During the monitoring period, 35 rainfall events were recorded, these ranging from 6.9 to $100.6 \mathrm{~mm}$. The strong contrasts in quantity and intensity (within and between years) of torrential rains were characterised by the discharge of great amounts of water in short periods of time. Figure 2 shows the rainfall intensities for storms, $I_{30}$, ranging from 1.2 to $22.9 \mathrm{~mm} \mathrm{~h}^{-1}$ for the study period. The highest rainfall and intensity in the study area peaked in the 6th and 23rd events, which were recorded in the experimental area in autumn and winter, respectively.

The annual erosivity indexes $\left(\mathrm{EI}_{30}\right)$ varied considerably, the highest values occurring during the first year. The annual erosivity for the monitoring period using $\mathrm{EI}_{30}$ ranged from 24.4 to $92.4 \mathrm{MJ} \mathrm{mm} \mathrm{ha}^{-1} \mathrm{~h}^{-1}$. This variability is particular to Mediterranean Europe, which is subject to strong spatial and temporal oscillations in weather (Aronica and Ferro, 1997; Renschler et al., 1999; Ramos, 2002), especially in rainfall erosivity, which is extremely important for risk assessment of soil erosion. 


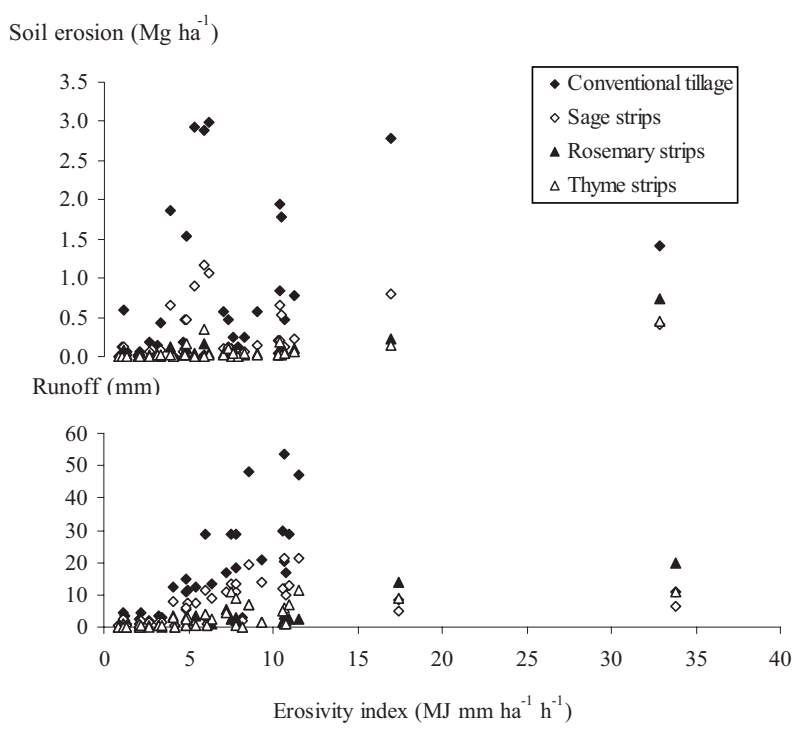

Figure 3. Linear relationships among soil erosion, runoff and erosivity index for each soil-management system. For soil erosion vs. erosivity index, in rosemary strips $r=0.86$ at $P<0.01$; in thyme strips $r=0.72$ at $P<0.01$. For runoff vs. erosivity index, in sage strips $r=0.41$ at $P<0.05$; in rosemary strips $r=0.86$ at $P<0.01$; in thyme strips $r=0.67$ at $P<0.01$ level.

Figure 3 presents the relationships of the erosivity index with soil erosion and runoff, showing that both were strongly correlated $(P<0.01)$, especially in the rosemary with $y=-55.8+18.0 x$ and $y=-1.28+0.57 x$, and thyme with $y=-27.8+11.7 x$ and $y=0.23+0.39 x$, respectively. On the contrary, both sage and conventional-tillage plots were not highly correlated, with an erosivity index on an event basis. Therefore, the linear model for the least eroded treatments, non-tillage with rosemary strips and non-tillage with thyme strips, gave the best fit for the study area under our experimental conditions. On the other hand, significant relationships $(P<0.01)$ were found between the rainfall amount and runoff for all the soil-management systems (Fig. 4). In relation to soil erosion, only non-tillage with rosemary strips with $y=-65.9+3.82 x$, and non-tillage with thyme strips with $y=-40.4+2.66 x$ were moderately correlated with rainfall amount. In general, the high variability in rainfall events with different erosivity indexes were significantly correlated only for the sage and thyme strips during the four-year monitoring period.

\subsection{Soil loss and runoff response to soil-management systems}

Table I shows the results for one-way analysis of variance (ANOVA) concerning the effect of the soil-management systems on the average soil loss and runoff. In the plantstrip plots, values for soil erosion and runoff differed significantly $(P<0.01)$ from those of the conventional tillage in the experimental area. The lowest soil erosion and runoff values were determined in 2005 , when the lowest rainfall was
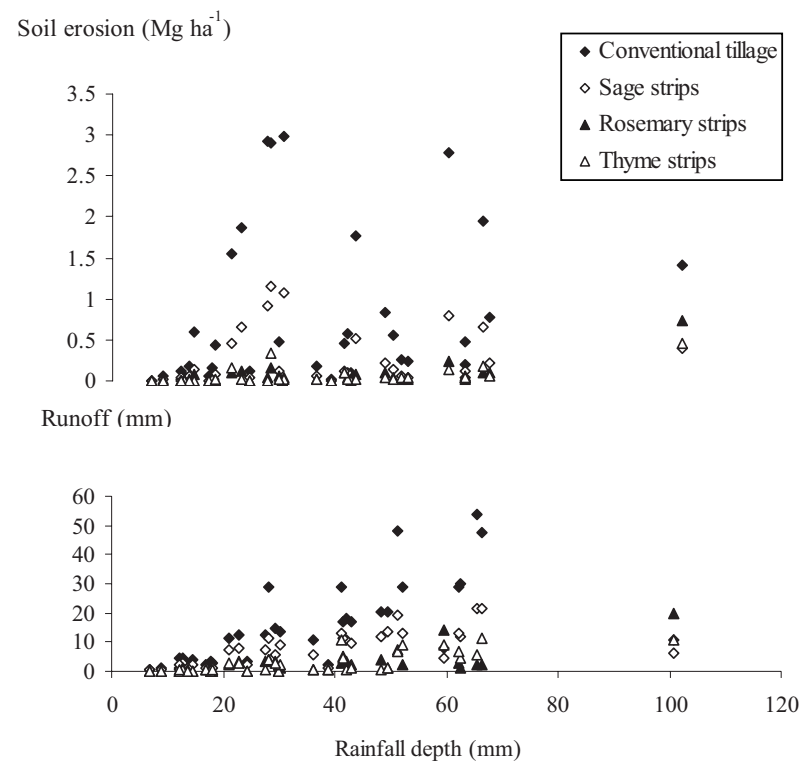

Figure 4. Linear relationships among soil erosion, runoff and rainfall for each soil-management system. For soil erosion vs. rainfall, in rosemary strips $r=0.64$ at $P<0.01$; in thyme strips $r=0.57$ at $P<0.01$. For runoff vs. rainfall, in sage strips $r=0.67$ at $P<0.01$; in rosemary strips $r=0.69$ at $P<0.01$; in thyme strips $r=0.76$ at $P<0.01$; in conventional tillage $r=0.65$ at $P<0.01$ level.

Table I. Average soil erosion and runoff for storm events.

\begin{tabular}{lcc}
\hline Soil-management system & $\begin{array}{c}\text { Soil erosion } \\
\left(\mathrm{kg} \mathrm{ha}^{-1}\right)\end{array}$ & $\begin{array}{c}\text { Runoff } \\
(\mathrm{mm})\end{array}$ \\
\hline Non-tillage with thyme strips & $52.9 \mathrm{a}$ & $2.9 \mathrm{a}$ \\
Non-tillage with rosemary strips & $67.9 \mathrm{a}$ & $2.6 \mathrm{a}$ \\
Non-tillage with sage strips & $238.7 \mathrm{a}$ & $7.2 \mathrm{a}$ \\
Conventional tillage & $774.9 \mathrm{~b}$ & $15.0 \mathrm{~b}$ \\
ANOVA & & \\
SMS $^{\mathrm{a}}$ & $* *$ & $* *$ \\
\hline
\end{tabular}

Values with different letters within the columns are statistically different at $P<0.01$ by Least Significant Difference (LSD) analysis; a Soilmanagement system; $* *$ Significant at $P<0.01$.

recorded (Tab. II). The soil erosion and runoff rates, ranging from 0.20 to $0.70 \mathrm{Mg} \mathrm{ha}^{-1} \mathrm{yr}^{-1}$ and from 21.7 to $30.4 \mathrm{~mm} \mathrm{yr}^{-1}$, respectively, over the entire study period, were measured under non-tillage with thyme strips. In non-tillage with rosemary strips, erosion ranged from 0.20 to $1.30 \mathrm{Mg} \mathrm{ha}^{-1} \mathrm{yr}^{-1}$ and runoff from 5.80 to $48.3 \mathrm{~mm} \mathrm{yr}^{-1}$, and in the non-tillage with sage strips, erosion ranged from 0.30 to $4.0 \mathrm{Mg} \mathrm{ha}^{-1} \mathrm{yr}^{-1}$ and runoff from 31.5 to $96.0 \mathrm{~mm} \mathrm{yr}^{-1}$ while under conventional tillage, soil erosion ranged from 1.3 to $11.8 \mathrm{Mg} \mathrm{ha}^{-1} \mathrm{yr}^{-1}$ and runoff from 69.2 to $184.3 \mathrm{~mm} \mathrm{yr}^{-1}$. Throughout the entire experimental period, the treatments non-tillage with sage strips and conventional tillage reached the highest soil erosion and runoff rates during 2003. The greatest total rainfall was $384.5 \mathrm{~mm}$, very irregularly distributed throughout the year, with 5 events of maximum intensity at 30 minutes $I_{30}>13 \mathrm{~mm} \mathrm{~h}^{-1}$ (value given as the erosive threshold 
Table II. Annual rainfall characteristics, soil erosion and runoff for the study period.

\begin{tabular}{|c|c|c|c|c|c|c|c|c|c|c|c|}
\hline Year & $\begin{array}{c}\text { Rainfall } \\
(\mathrm{mm})\end{array}$ & $\begin{array}{l}\text { Intensity at } \\
30 \mathrm{~min}, I_{30} \\
\left(\mathrm{~mm} \mathrm{~h}^{-1}\right)\end{array}$ & $\begin{array}{c}\text { Erosivity index, } \\
\mathrm{E} I_{30} \\
\left(\mathrm{MJ} \mathrm{mm} \mathrm{ha-1} \mathrm{h}^{-1}\right)\end{array}$ & \multicolumn{2}{|c|}{$\begin{array}{c}\text { Non-tillage with } \\
\text { thyme strips }\end{array}$} & \multicolumn{2}{|c|}{$\begin{array}{l}\text { Non-tillage with } \\
\text { rosemary strips }\end{array}$} & \multicolumn{2}{|c|}{$\begin{array}{c}\text { Non-tillage with } \\
\text { sage strips }\end{array}$} & $\begin{array}{c}\begin{array}{c}\text { Conventional } \\
\text { tillage }\end{array} \\
\begin{array}{c}\text { Soil erosion } \\
\left(\mathrm{Mg} \mathrm{ha}^{-1}\right)\end{array}\end{array}$ & $\begin{array}{l}\text { Runoff } \\
(\mathrm{mm})\end{array}$ \\
\hline 2nd & 384.5 & 174.0 & 71.1 & 0.7 & 28.9 & 0.6 & 29.0 & 4.0 & 96.0 & 11.8 & 184.3 \\
\hline $3 \mathrm{rd}$ & 313.1 & 54.6 & 52.9 & 0.4 & 30.4 & 0.3 & 9.5 & 1.1 & 70.1 & 3.6 & 165.0 \\
\hline 4 th & 149.2 & 43.5 & 24.4 & 0.2 & 21.7 & 0.2 & 5.8 & 0.3 & 31.5 & 1.3 & 69.2 \\
\hline
\end{tabular}

by Wischmeier and Smith, 1978). On the contrary, the nontillage with thyme strip and non-tillage with rosemary strip treatments registered the highest values during 2002 with only one event of intensity $I_{30}>13 \mathrm{~mm} \mathrm{~h}^{-1}$. All this is consistent with the $\mathrm{E}_{30}$ recorded for the study period. Therefore, the high variability in rainfall amount and intensity from one year to another during the study period resulted in a broad range of soil loss and runoff values.

In our field study on a hillside with $35 \%$ slope, the highest rates for erosion and runoff in a conventional tillage plot were $11.8 \mathrm{Mg} \mathrm{ha}^{-1} \mathrm{yr}^{-1}$ and $184.3 \mathrm{~mm} \mathrm{yr}^{-1}$, respectively. For conventional tillage in the study zone (Lanjarón, SE Spain) Francia et al. (2006), studying olive orchards (30\% slope), found maximum soil erosion and runoff rates of $10.4 \mathrm{Mg} \mathrm{ha}^{-1} \mathrm{yr}^{-1}$ and $15.2 \mathrm{~mm} \mathrm{yr}^{-1}$, respectively. This difference, especially for the runoff, was probably due to the denser canopy of olive trees, which intercepts part of the rainfall before the water reaches the soil surface (by stemflow and leaf drip), diminishing soil-surface sealing by direct raindrop impact. In a mature almond orchard with conventional tillage under even more extreme conditions than ours, van Wesemael et al. (2006) estimated higher erosion rates $\left(26.6 \mathrm{Mg} \mathrm{ha}^{-1} \mathrm{yr}^{-1}\right)$ than those found in the present experiment.

According to our findings, the effectiveness of non-tillage with thyme strips, non-tillage with rosemary strips and nontillage with sage strips to reduce soil loss with respect to the conventional tillage was 93,91 and $69 \%$, and for the runoff 80,82 and $51 \%$, respectively. These results imply that the biomass of plant-cover strips across the slope significantly reduced erosion by cutting down surface runoff and buffering the rainfall impact on the ground surface. The intercepted rainfall, diverted to leaf drip or stemflow, reached the soil surface with lower kinetic energy than the non-intercepted rainfall. The plant morphology seemed to be an important factor in intercepting rainfall and therefore in reducing soil loss and runoff (Bochet et al., 2000; Isselin-Nondedeu and Bédécarrats, 2007). That is, thyme knitted to the soil surface, forming a carpet of fine leaves and stems that restrained runoff and therefore soil sediments (Martínez et al., 2006). Also, the leaf litter that accumulated beneath the cover strip appeared to be more effective at discouraging runoff during rainstorms than in the rosemary or sage covers. Meanwhile, the sage plants, growing with a more open habit, allowed rainfall to penetrate more easily and restrained runoff and soil sediments to a lesser degree. In addition, the highest percentages of soil covered correlated with the lowest rates of soil erosion and runoff. Thus, rosemary and thyme, having the densest cover with $78 \%$ and $85 \%$ of soil covered, gave the lowest runoff and erosion values, and, conversely, the lowest percentage of cover of $60 \%$ was found under salvia, which registered the highest runoff and soil loss rates among the plant strips used. In comparative terms among the shrub strips tested, the thyme and rosemary covers reduced soil loss by $76 \%$ and $71 \%$, and runoff by $59 \%$ and $63 \%$, respectively, with respect to sage. In this sense, the plant biomass, living or dead, of shrub-cover strips between rows of almond trees, according to our results protected and reduced soil erosion and runoff because raindrop energy was dissipated. Thereby presumably increasing water infiltration and the water-storage capacity of the soil, this is reflected in each recorded rainfall event during the study period in comparison with the conventional tillage treatment. Also, the level of organic matter and essential plant nutrients under plant cover increased the natural biomass. According to Durán et al. (2006), the content of soil organic carbon increases under aromatic shrubs, which boosts the available organic matter, and consequently the soil quality by influencing a major repository and reserve of plant nutrients (Pimentel et al., 1980; Vitousek, 1998; Sánchez et al., 2002).

Thus, the soil degradation was reduced by planting cover strips of plants with aromatic, medicinal and mellipherous properties, decreasing the soil erosion risk on steep slopes with almond orchards adapted to these arid conditions. In this environment, the plant strips helped to harvest rainfall by reducing the runoff across the hillslope. In this sense, the aromatic-shrub covers offer not only crop benefits but also constitute a major advantage in soil and water conservation.

\subsection{Nutrient losses by runoff and risk of potential pollution}

Table III shows the results for the total inorganic nitrogen, phosphorus and potassium losses per area (dischargeweighted) by runoff, and for each soil-management system during the four-year monitoring period. The greatest total nitrogen flux was from the conventional tillage plot of $1415.2 \mathrm{mg} \mathrm{m}^{-2}$, with a decreasing trend from non-tillage with sage strips of $290.8 \mathrm{mg} \mathrm{m}^{-2}$, and non-tillage with rosemary strips of $123.6 \mathrm{mg} \mathrm{m}^{-2}$ to non-tillage with thyme strips of $78.6 \mathrm{mg} \mathrm{m}^{-2}$; similarly, the $\mathrm{P}$ and $\mathrm{K}$ increased in the same order: conventional tillage $>$ non-tillage with sage strips $>$ non-tillage with rosemary strips $>$ non-tillage with thyme 
Table III. Nutrient losses by runoff for erosive events for the study period (2002-2005).

\begin{tabular}{lcccccccccccc}
\hline & \multicolumn{2}{c}{$\begin{array}{c}\text { Non-tillage with } \\
\text { thyme strips }\end{array}$} & \multicolumn{3}{c}{$\begin{array}{c}\text { Non-tillage with } \\
\text { rosemary strips }\end{array}$} & \multicolumn{2}{c}{$\begin{array}{c}\text { Non-tillage with } \\
\text { sage strips }\end{array}$} & \multicolumn{2}{c}{$\begin{array}{c}\text { Conventional } \\
\text { tillage }\end{array}$} \\
\hline & $\mathrm{N}^{\mathrm{a}}$ & $\mathrm{P}$ & $\mathrm{K}$ & $\mathrm{N}$ & $\mathrm{P}$ & $\mathrm{K}$ & $\mathrm{N}$ & $\mathrm{P}$ & $\mathrm{K}$ & $\mathrm{N}$ & $\mathrm{P}$ \\
\hline & & & & & & $\left(\mathrm{mg} \mathrm{m}^{-2}\right)$ & & & & & \\
Average & 2.2 & 1.2 & 3.2 & 3.5 & 1.5 & 6.9 & 8.3 & 4.2 & 13.4 & 40.4 & 10.2 & 36.2 \\
S.D. & 2.9 & 2.0 & 4.8 & 6.1 & 2.2 & 12.4 & 11.5 & 5.3 & 23.2 & 48.2 & 12.3 & 59.1 \\
Max. & 10.5 & 8.9 & 16.2 & 32.1 & 7.9 & 57.1 & 59.2 & 21.0 & 115.6 & 245.9 & 52.2 & 318.3 \\
Min. & 0.0 & 0.0 & 0.0 & 0.0 & 0.0 & 0.0 & 0.1 & 0.0 & 0.1 & 0.5 & 0.1 & 0.3 \\
Total & 78.6 & 41.3 & 111.6 & 123.6 & 54.0 & 240.3 & 290.8 & 147.4 & 467.6 & $1,415.2$ & 355.6 & $1,266.5$ \\
$\mathrm{~N}$ & 35 & 35 & 35 & 35 & 35 & 35 & 35 & 35 & 35 & 35 & 35 & 35 \\
\hline
\end{tabular}

${ }^{\text {a }} \mathrm{NO}_{3}-\mathrm{N}+\mathrm{NH}_{4}-\mathrm{N}$ (Inorganic nitrogen); S.D.: standard deviation.

strips. The highest rates for NPK losses by runoff were recorded during the third and fourth years, and all the time from conventional tillage. For the two years 2004 and 2005, the annual rainfall was 313.1 and $149.2 \mathrm{~mm}$, respectively, and the runoff, especially for the last year, was lower than the other years but with the highest concentration of nutrients.

The $\mathrm{N}$ transported by runoff from the four treatments suggests that the dissolved nitrogen came mainly from $\mathrm{N}$ fertilisers $\left(\mathrm{NH}_{4} \mathrm{NO}_{3}\right.$ and $\left.\mathrm{KNO}_{3}\right)$ applied to the plot, rather than from the soil, and the same applies to the dissolved $\mathrm{NH}_{4}^{+}$contained in the runoff $\left(\mathrm{NH}_{4} \mathrm{NO}_{3}, \mathrm{NH}_{4} \mathrm{SO}_{4}\right.$ and $\left.\mathrm{NH}_{4} \mathrm{H}_{2} \mathrm{PO}_{4}\right)$. Also, an appreciable amount of dissolved potassium resulted in $\mathrm{K}$-rich runoff, presumably from $\mathrm{K}$ fertilisers $\left(\mathrm{K}_{2} \mathrm{SO}_{4}, \mathrm{KH}_{2} \mathrm{PO}_{4}\right.$ and $\mathrm{KNO}_{3}$ ). The amount of $\mathrm{P}$ per area in the conventional tillage, non-tillage with sage strips, non-tillage with rosemary strips and non-tillage with thyme strips was 127.6, 63.7, 21.9 and $17.6 \mathrm{mg} \mathrm{m}^{-2}$, respectively, which were according to the runoff generated in each treatment, the probable source being readilysoluble $\mathrm{P}$ fertilisers $\left(\mathrm{NH}_{4} \mathrm{H}_{2} \mathrm{PO}_{4}\right.$ and $\left.\mathrm{KH}_{2} \mathrm{PO}_{4}\right)$ applied to the field. Thus, the higher loss of nutrients in the runoff from conventional tillage resulted from accumulations over time, at or near the soil surface from the yearly application of fertilisers, these processes occurring as rainfall interacted with a thin layer of surface soil. Heavy losses of nutrients occurred with rainfall events shortly after spring and autumn fertiliser application. In this sense, NPK losses may have decreased in all plants' strip treatments through sorption by soil and litter, especially during infiltration, and through assimilation by plants and microbes (Peterjohn and Correll, 1984).

\subsection{Almond and essential oil yield}

The average yield of almond trees for non-tillage with sage strip, non-tillage with rosemary strip, non-tillage with thyme strip and conventional tillage treatments during the study period was $2.4 \pm 0.6,3.2 \pm 0.9,3.8 \pm 0.9$ and $4.5 \pm 0.7 \mathrm{~kg}$ tree $^{-1}$, respectively (Fig. 5), which represented the potential yield of $500.0,668.5,792.0$ and $945.3 \mathrm{~kg} \mathrm{ha}^{-1}$, respectively. The lowest yield per hectare was harvested under sage strips and the best among the shrub strips in thyme strips, which decreased the yield by $0.7 \mathrm{~kg}$ tree $^{-1}$ with respect to the conventional tillage. The yield oscillated among the study years,

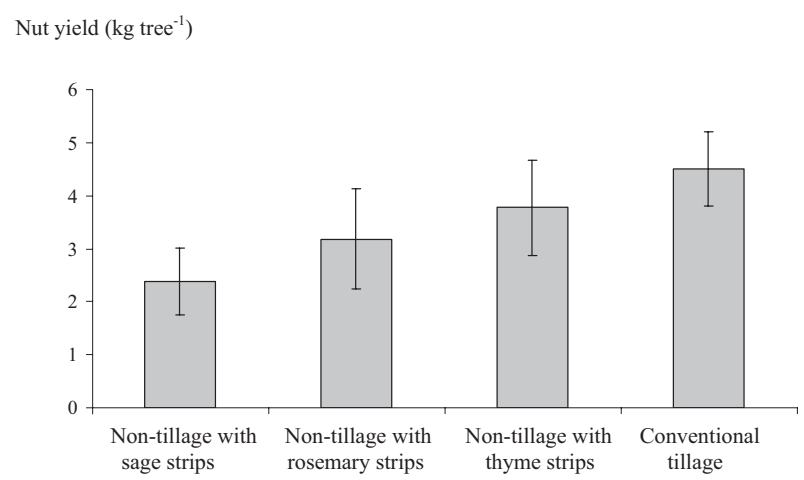

Figure 5. Average nut yield from almond trees for the four-year monitoring period. Vertical bars represent standard deviation.

being higher for the first and second years, which coincided with the greatest amounts of rainfall (Tab. II). In this context, in other Spanish Mediterranean regions, almond production under similar conditions (rainfed with inorganic fertilisers) in almond orchards is about $5.4 \mathrm{~kg} \mathrm{tree}^{-1}$ (Valverde et al., 2006). Thus, the negative effect on yield of almond trees on hillslopes by cultivating plant strips of thyme, rosemary and sage in relation to conventional tillage was 16, 29 and 47\%, respectively.

The average fresh biomass yield from rosemary, sage and thyme plants was $505.1,549.3$ and $665.3 \mathrm{kgha}^{-1}$, respectively (Fig. 6). Since each shrub has a different height and shape, the biomass yields differ (thyme being lower than open medium-sized rosemary and sage plants). The biomass yield for rosemary and thyme varied more than sage during the study period. In addition, the essential oil content $(\mathrm{v} / \mathrm{w})$ for sage, rosemary and thyme was 1.20, 2.20 and 1.90\%; consequently, the potential yield in essential oils was $5.0 \pm 2.3$, $8.7 \pm 7.3$ and $10.8 \pm 7.5 \mathrm{~L} \mathrm{ha}^{-1}$, respectively. These yields are acceptable, taking into account that from one hectare of almond trees only $50 \%$ is cultivated with shrub strips $3 \mathrm{~m}$ wide - that is, about 16 strips running across the hillslope. As these plants are perennial plants and grow year round, they compete unsuitably with the almond orchard for water. Therefore, the main drawback is the water availability between the shrub strips and almond trees, provoking lower almond yields, with respect to conventional tillage without plant strips. Although the highest runoff rates were in conventional tillage the 


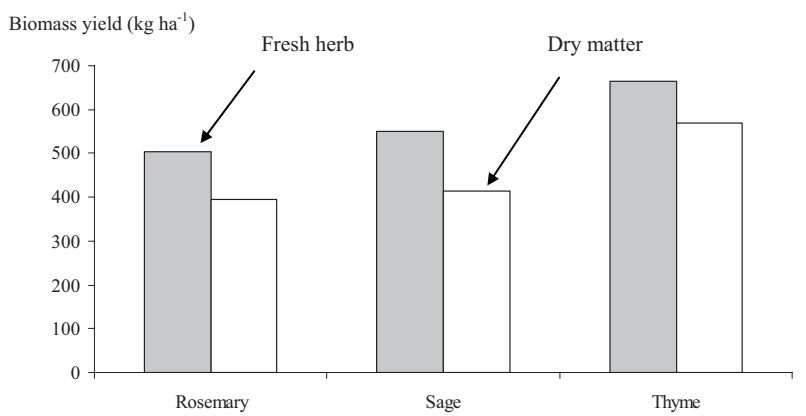

Figure 6. Average biomass yield of aromatic and medicinal plant strips for the four-year monitoring period.

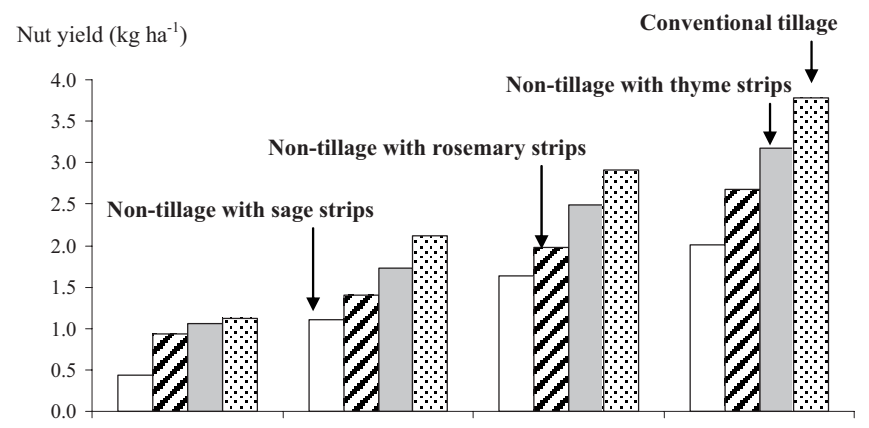

Essential oil yield $\left(\mathrm{L} \mathrm{ha}^{-1}\right)$

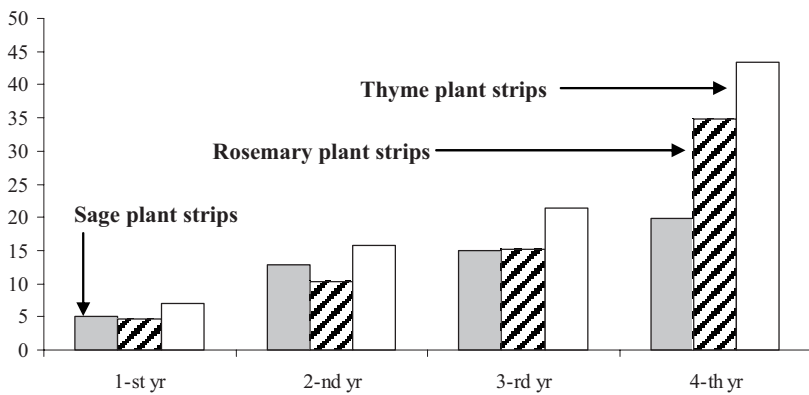

Figure 7. Cumulative nut and essential oil yield for each soilmanagement system for the four-year monitoring period.

rainfall water infiltration rate in recently tilled soil is usually higher, but this effect of tillage disappears in a relatively short time (Goméz et al., 1999). This early infiltrated rainfall water could be crucial in conventional tillage by increasing the almond yield in comparison with the other treatments.

A complete tally of cumulative annual almond and essential oil yield for the plant strips in each treatment over the four study years is shown in Figure 7. From the results the cumulative almond yield under conventional tillage, non-tillage with thyme strips, non-tillage with rosemary strips and nontillage with sage strips was 3.8, 3.2, 2.7 and $2.0 \mathrm{tha}^{-1}$, respectively, and the essential oil yield from thyme, rosemary and sage plants was $43.3,34.7$ and $19.9 \mathrm{~L} \mathrm{ha}^{-1}$, respectively.

Spain, with 28000 ha, is the largest producer of herbs in the European Community (Verlet, 1992), the great majority of these materials being collected from wild resources, while most medicinal plants are traded locally and regionally rather than internationally. The demand for aromatic and medicinal plants for the pharmaceutical, food, cosmetic and perfume industries is increasing, and therefore, it will be advantageous to promote the cultivation of these plants instead of wild harvest, which can degrade marginal mountainous areas (More and Colom, 2002; Durán et al., 2008). The strip cultivation of medicinal and aromatic shrubs under rainfed conditions on semi-arid slopes could provide an economic income for farmers, as the prices of essential oil of sage, rosemary and thyme are about 50,70 and $70 €$ per litre, respectively. For the farmer the price of almonds is about $1.06 €$ per $\mathrm{kg}$, and therefore the mean income from conventional tillage, non-tillage with sage strip, non-tillage with rosemary strip, and non-tillage with thyme strip treatments could be approximately 1002, 780, 1318 and $1596 €$ per ha, respectively. Moreover, the aid for almond farmers from the European Union and local government is $241.5 €$ per ha.

Plant-cover strips in rainfed crops such as olive are normally a non-economic crop grown in the middle between orchard rows, using mainly annual plants (barley, wheat, lentil, etc.) (Francia et al., 2006). However, perennial aromatic shrubs could provide an additional economic income for almond farmers, as shown from the results of the present experiment. Since the wild collection of medicinal and aromatic plants in the study zone is ecologically untenable, and intense farming systems of mountain areas endanger soil conservation, there is an urgent need to implement appropriate land management which presents a large-scale perspective but acts at the local level. In this sense, the cultivation of both almond trees and aromatic shrubs could be an initiative to develop a good practice for sustainable agriculture.

In addition, erosion decreases the diversity and abundance of soil organisms, and the soil biota is vital for soil quality and productivity, as well as for the recycling of basic nutrients required by plants for their growth (Pimentel et al., 1980, 1997). Diversification of existing mountain-farming systems, by developing suitable agro-friendly measures (pollution and erosion control, restoring soil quality) could satisfy the needs of modern agriculture while responding to the growing demand for maintaining or recovering the environment.

\section{CONCLUSION}

The integration of cultivated plant strips on farmland improves the existing systems, by fomenting complex biological interactions and controlling erosion and pollution. Diversification and sustainability in production are the two main goals in agriculture, that can be achieved in almond orchards by planting aromatic and medicinal plant species. In this sense, thyme was perhaps the most beneficial plant to use in the strips between rows of almond trees, providing an effective system for trapping runoff as well as reducing soil erosion, thereby avoiding the pollution of the water bodies receiving these effluents. In addition, the thyme and rosemary strips led to a loss in the almond harvest, a loss that could be completely offset by the economic value of the thyme and rosemary crops. Yield losses 
can be offset not only over the short term by the benefits of harvesting the plant strips but also over the long term by preserving soil and water quality. Thus, cultivation of medicinal and aromatic herbs (medicinal, aromatic, culinary and mellipherous), especially thyme, on semi-arid slopes with almond orchards can provide a positive impact on the environment while maintaining reasonable yield.

Acknowledgements: This research has been partly sponsored by the two following Research Projects: "Environmental study of dry-fruit trees cultivation in mountainous areas in Mediterranean climate: rainfed almond and irrigated walnut orchards (PIA 03-001)" granted by the IFAPA of the Junta de Andalucia and "Protective and regenerator behaviour of some aromaticmedicinal species for soils in Granada and Almeria. Essential-medicinal interest of these species and its incidence in the environment (RTA04-012)" granted by the INIA Spain.

\section{REFERENCES}

APHA, AWWA, WPCF (1995) Standard Methods for the Examination of Water and Wastewater, 17th ed., American Public Health Association, Washington DC, USA.

Aranda V., Oyonarte C. (2005) Effect of vegetation with different evolution degree on soil organic matter in a semi-arid environment (Cabo de Gata-Níjar Natural Park, SE Spain), J. Arid Environ. 62, 631-647.

Aronica G., Ferro V. (1997) Rainfall erosivity over the Calabrian region, Hydrol. Sci. J. 42, 35-48.

Arshad M.A., Martin S. (2002) Identifying critical limits for soil quality indicators in agro-ecosystems, Agr. Ecosyst. Environ. 88, 153-160.

Basile B., Reidel E.J., Weinbaum S.A., DeJong T.M. (2003) Leaf potassium concentration, $\mathrm{CO}_{2}$ exchange and light interception in almond trees (Prunus dulcis (Mill) D.A. Webb), Sci. Hortic. 98, 185-194.

Beaufoy G. (2003) The environmental impact of olive oil production in the European Union - practical options for improving the environmental impact, European Forum on Nature Conservation and Pastoralism and Asociación para el Análisis y Reforma de la Política, Agro-rural, Available on line at: http://europa.eu.int/comm/environment/agriculture/.

Blanco E., Fernández M.D., Muñoz F. (1996) Plantas medicinales, Incidencia ambiental y económica del uso de las plantas aromáticas y medicinales en España, Informe Técnico, ADENA Fondo Mundial para la Naturaleza, Madrid, Spain.

Blanco E., Morales R., Pellin R. (1998) Harvesting and trade of thymus in Spain, in: TRAFFIC Europe (Ed.), Medicinal plant trade in Europe: conservation and supply, Proceedings of 1st International Symposium on the Conservation of Medicinal Plants in Trade, Brussels, Belgium, pp. 50-54.

Bochet E., Poesen J., Rubio J.L. (2000) Mound development as an interaction of individual plants with soil, water erosion and sedimentation processes on slopes, Earth. Surf. Process. Landforms 25, 847867.

Bogers R.J., Craker L.E., Lange D. (2006) Medicinal and aromatic plants, Springer, The Netherlands.

Bown D. (2001) New Encyclopedia of Herbs and Their Uses, Dorling Kindersley Ltd., London, England.

Brandt C.J., Thornes J.B. (1996) Mediterranean Desertification and Land Use, Wiley, Chichester, UK.

De Alba S. (2003) Simulating long-term soil redistribution generated by different patterns of mouldboard ploughing in landscapes of complex topography, Soil Till. Res. 71, 71-86.
Durán Z.V.H., Francia J.R., Martínez R.A. (2004a) Impact of vegetative cover on runoff and soil erosion at hillslope scale in Lanjaron, Spain, Environmentalist 24, 39-48.

Durán Z.V.H., Martínez R.A., Aguilar R.J. (2004b) Nutrient losses by runoff and sediment from the taluses of orchard terraces, Water Air Soil Poll. 153, 355-373.

Durán Z.V.H., Francia J.R., Rodríguez C.R.P., Martínez R.A., Cárceles R.B. (2006) Soil-erosion and runoff prevention by plant covers in a mountainous areas (SE Spain): implications for sustainable agriculture, Environmentalist 26, 309-319.

Durán Z.V.H., Rodríguez C.R.P., Francia J.R., Cárceles R.B., Martínez R.A., Galindo P.P. (2008) Harvest intensity of aromatic shrubs vs. soil erosion: An equilibrium for sustainable agriculture (SE Spain), Catena 73, 107-116.

FAO (1974) Soil map of the world, Legend, Paris, France, Vol. 1, 50 p.

FAOSTAT (2007) Available on line at: http: // faostat.fao.org /site/567/DesktopDefault.aspx?PageID=567. Available [2007, 30 October].

Faulkner H., Alexander R., Wilson B.R. (2003) Changes to the dispersive characteristics of soils along an evolutionary slope sequence in the Vera badlands, southeast Spain: implications for site stabilisation, Catena 50, 243-254.

Francia J.R., Durán Z.V.H., Martínez R.A. (2006) Environmental impact from mountainous olive orchards under different soil-management systems (SE Spain), Sci. Total Environ. 358, 46-60.

Franco J.A., Abrisqueta J.M., Hernandez A., Moreno F. (2000) Water balance in a young almond orchard under drip irrigation with water of low quality, Agr. Water Manage. 43, 75-98.

Goméz J.A., Giráldez J.V., Pastor M., Fereres E. (1999) Effects of tillage method on soil physical properties, infiltration and yield in an olive orchard, Soil Till. Res. 52, 167-175.

Isselin-Nondedeu F., Bédécarrats A. (2007) Influence of alpine plants growing on steep slopes on sediment trapping and transport by runoff, Catena 71, 330-339.

Lange D. (1998) Europe's medicinal and aromatic plants: their use, trade and conservation, TRAFFIC International, Cambridge, UK.

Lawrence B.M. (1985) A review of the world production of essential oils, Perfumer Flavorist 10, 1-16.

Le Bissonnais Y., Lecomte V., Cerdan O. (2004) Grass strip effects on runoff and soil loss, Agronomie 24, 129-136.

Martínez R.A., Durán Z.V.H., Francia J.R. (2006) Soil erosion and runoff response to plant-cover strips on semi-arid slopes (SE Spain), Land Degrad. Dev. 17, 1-11.

Miguel G., Simões M., Figueiredo A.C., Barroso J.G., Pedro L.G., Carvalho L. (2004) Composition and antioxidant activities of the essential oils of Thymus caespititius, Thymus camphoratus and Thymus mastichina, Food Chem. 86, 183-188.

More P.E., Colom G.A. (2002) Distribución comercial de plantas aromáticas y medicinales en Cataluña, Prod. Protec. Veg. 17, 43-66.

MSC (1997) Determinación de aceites esenciales en drogas vegetales, in: Ministerio de Sanidad y Consumo (Ed.), Métodos de farmacognesia, Real Farmacopea Española, Madrid, Spain, pp. 125-126.

Oñate J.J., Peco B. (2005) Policy impact on desertification: stakeholders' perceptions in southeast Spain, Land Use Policy 22, 103-114.

Owino J.O., Owido S.F.O., Chemelil M.C. (2006) Nutrients in runoff from a clay loam soil protected by narrow grass strips, Soil Till. Res. 88, 116-122.

Peterjohn W.T., Correll D.L. (1984) Nutrient dynamics in agricultural watershed: observations on the role of a riparian forest, Ecology 65, $1466-1475$.

Pimentel D. (2000) Soil erosion and the threat to food security and the environment, Ecosyst. Health 6, 221-226.

Pimentel D. (2006) Soil erosion: a food and environmental threat. Environ. Dev. Sustain. 8, 119-137. 
Pimentel D., Garnick E., Berkowitz A., Jacobson S., Napolitano S., Black P., Valdes C.S., Vinzant B., Hudes E., Littman S. (1980) Environmental quality and natural biota, Bioscience 30, 750-755.

Pimentel D., Harvey C., Resosudarmo P., Sinclair K., Kurz D., McNair M., Crist S., Sphpritz L., Fitton L., Saffouri R., Blair R. (1995) Environmental and economic costs of soil erosion and conservation benefits, Science 267, 1117-1123.

Pimentel D., Wilson C., McCullum C., Huang R., Dwen P., Flack J., Tran Q., Saltman T., Cliff B. (1997) Economic and environmental benefits of biodiversity, Bioscience 47, 747-757.

Ramos M.C. (2002) Differences on the characteristics of the storms recorded along the year in a Mediterranean climate. Intensity and kinetic energy, in: Mugnai A., Guzzetti F., Roth G. (Eds.), Mediterranean Storms, 2nd Plinius Conference European Geophysical Society, Pub. GNDCI No. 2547, pp. 431-440.

Renschler C.S., Mannaerts C., Diekkruger B. (1999) Evaluating spatial and temporal variability in soil erosion risk-rainfall erosivity and soil loss ratios in Andalusia, Spain, Catena 34, 209-225.

Sánchez M.M., Soriano M., Delgado G., Delgado R. (2002) Soil quality in Mediterranean mountain environments: effects of land use change, Soil Sci. Soc. Am. J. 66, 948-958.

Sharpley A.N., Smith S.J., Ahuja L.R. (1988) Soluble potassium transport in agricultural runoff water, Agr. Water Manage. 15, 37-46.

Sharpley A.N., Tunney H. (2000) Phosphorus research strategies to meet agricultural and environmental challenges of the 21 st century, J. Environ. Qual. 29, 176-181.

Smith V.H., Tilman G.D., Nekola J.C. (1999) Eutrophication: impacts of excess nutrient inputs on freshwater, marine, and terrestrial ecosystems, Environ. Pollut. 100, 179-196.
Ulen B. (1997) Nutrient losses by surface runoff from soils with winter cover crops and spring-ploughed soils in the south of Sweden, Soil Till. Res. 44, 165-177.

Valverde M., Madrid R., Garcia A.L. (2006) Effect of irrigation regime, type of fertilization, and culture year on the physical properties of almond (cv. Guara), J. Food Eng. 76, 584-593.

van Oost K., Govers G., van Muysen W., Quine T.A. (2000a) Modelling translocation and dispersion of soil constituents by tillage on sloping land, Soil Sci. Soc. Am. J. 64, 1733-1739.

van Oost K., Govers G., Desmet P. (2000b) Evaluating the effects of changes in landscape structure on soil erosion by water and tillage, Land. Ecol. 15, 577-589.

van Wesemael B., Rambaud X., Poesen J., Muligan M., Cammeraat E., Stevens A. (2006) Spatial patterns of land degradation and their impacts on the water balance of rainfed treecrops: A case study in South East Spain, Geoderma 133, 43-56.

Verlet N. (1992) The world herbs and essential oils economy-analysis of a medium term development, Acta Hortic. 306, 474-481.

Vitousek P.M. (1998) Foliar and litter nutrients, nutrient resorption, and decomposition in Hawaiian Metrosideros polymorpha, Ecosystems 1, 401-407.

Wang G., Ma H., Qian J., Chang J. (2004) Impact of land use changes on soil carbon, nitrogen and phosphorus and water pollution in an arid region of northwest China, Soil Use Manage. 20, 32-39.

Weiss E.A. (1997) Essential oil crops, CAB International, Oxon, UK.

Wischmeier W.H., Smith D.D. (1978) Predicting rainfall erosion losses: a guide to conservation planning, USDA-ARS Agric. Handbook, 537, Washington, USA. 